Estudios sobre armas antiguas, arte militar $\mathrm{y}$ vida cultural en oriente y occidente

XXXV (2015), pp. 7-20

ISSN: 0436-029X

doi: 10.3989/gladius.2015.0001

\title{
WARFARE AND SOCIO-POLITICAL HIERARCHIES: REFLECTIONS ON NON-STATE SOCIETIES OF THE PREDYNASTIC NILE VALLEY
}

\author{
GUERRA Y JERARQUÍAS SOCIOPOLÍTICAS: REFLEXIONES SOBRE \\ LAS SOCIEDADES NO ESTATALES DEL VALLE DEL NILO PREDINÁSTICO
}

POR

\author{
Augusto Gayubas*
}

\section{Abstract - Resumen}

In a recent article, anthropologist Robert L. Carneiro reassessed his most debated hypothesis about the emergence of chiefdoms and the State as a result of environmental or social circumscription, theorized for a series of historical contexts including that of the Predynastic Nile Valley. The problem of the origin of the State is beyond our scope, but regarding the emergence of institutionalized leadership and chiefdoms in the Nile Valley, Carneiro's ideas about warfare as a main factor in the process of social change remain interesting, even when his insistence in circumscription is still debatable. The aim of the present paper is to briefly review the available archaeological evidence of warfare among non-State societies of the Predynastic Nile Valley, and to evaluate its possible relation to the emergence of socio-political hierarchies, in turn refering to and criticizing some of Carneiro's recent ideas about the issue.

En un artículo reciente, Robert L. Carneiro presentó una reconsideración de su muy debatida hipótesis acerca de la emergencia de sociedades de jefatura y del Estado como resultado de un contexto de circunscripción ambiental, teorizada para una serie de situaciones históricas, entre ellas el valle del Nilo predinástico. El problema del origen del Estado excede las posibilidades de este trabajo, pero en lo que respecta al surgimiento de jefaturas, consideramos que las ideas de Carneiro acerca de la guerra como factor de importancia en el proceso revisten cierto interés, aun cuando su insistencia en la circunscripción continúa siendo discutible. El objetivo del presente artículo es considerar la evidencia arqueológica de guerra disponible para las sociedades no estatales del valle del Nilo predinástico y evaluar la posible relación entre dichos testimonios y la emergencia de jerarquías sociopolíticas, refiriendo y criticando algunas de las ideas recientes de Carneiro sobre el problema.

\section{Keywords - Palabras Clave}

Warfare; chiefdom; Nile Valley; Predynastic period.

Guerra; jefatura; valle del Nilo; período Predinástico.

\footnotetext{
* Consejo Nacional de Investigaciones Científicas y Técnicas (CONICET) / Universidad de Buenos Aires. E-mail: augustogayubas@yahoo.com.ar.
} 
$1^{1}$.

In a recent article, anthropologist Robert L. Carneiro reassessed his most debated hypothesis about the emergence of chiefdoms and the State as a result of environmental or social circumscription, theorized for a series of historical contexts -including that of the Predynastic Nile Valley. The original formulation of the so-called "circumscription theory" asserts that population pressure caused by a geographic constriction -i.e. environmental circumscription - brought about warfare and, in turn, successive conquests that led to the emergence of chiefdoms and the State. Current reappraisal points out that circumscription doesn't necessarily initiate such a process - testimonies of chiefdom formation and State formation without a geographical constriction are mentioned by the anthropologist-; according to the author, circumscription can in certain circumstances only accelerate the process, assertion that is sustained in an explicit evolutionist view according to which "complexity" is a historical necessity, and in which resource concentration and competition remain central. In any way, in dealing with Egyptian Nile Valley, Carneiro maintains his idea that the key role in sociopolitical transformation is played by environmental circumscription ${ }^{2}$.

The problem of the origin of the State is beyond our scope, but regarding the emergence of institutionalized leadership and chiefdoms in the Nile Valley, it is worthy to note that Carneiro's ideas about conflict — and, in particular, about warfare - as a main factor in the process of social change remain interesting, even when his insistence in circumscription is still debatable.

The aim of the present paper is to briefly review the available evidence of warfare among non-State societies of the Predynastic Nile Valley, and to evaluate its possible relation to the emergence of socio-political hierarchies, in turn refering to and criticizing some of Carneiro's recent ideas about the issue.

\section{2.}

Archaeological testimonies allow us to infer the presence of human occupation in the Nile Valley as far back as the Paleolithic period. Since the end of the Paleolithic, there is more clear indication of hunting-gathering and fishing activities. By the Neolithic and early Predynastic periods (c. 5500-3600 BC), there is also evidence of the existence of cattle rising and an incipient agriculture, and of an increasing process of sedentarization. In terms of social organization, the evidence of the cemeteries of the Neolithic and early Predynastic periods — particularly the grouping of tombs in clusters, reflecting descent groups - indicate the importance of kinship as the main axis for the articulation of society. Badarian (c. 4500-3900 BC) and, more clearly, Naqada I (c. 3900-3600 BC) cemeteries also show signs of social differentiation - tombs differentiated by size and grave goods, leadership insignias-, usually interpreted as indicative of the existence of chiefdom societies ${ }^{3}$.

The questions arise: Is there evidence of warlike activities dated to these periods? Are there indications of a relation between warlike activities and socio-political hierarchies?

1 I wish to thank Sebastián Maydana for his help in correcting the English draft of this paper. I also wish to thank two anonymous reviewers for their comments on an earlier version of this paper.

2 See Carneiro, 1970; 2012.

3 Campagno \& Gayubas, 2015, 19-20. See Hendrickx \& Veermersch, 2000; Hendrickx, Huyge \& Wendrich, 2010. On kinship as the main axis for the articulation of society in Neolithic and early Predynastic periods, see Campagno, 2000a, 35-39; 2009. 
Archaeological evidence indicates the presence of warfare since the late Paleolithic period. Human remains with stone projectile points embedded in - and near the - body, have been found in individual and colective contexts - an adult male in Wadi Kubbaniya, dated to about 20,000 years ago; cemetery 117 at Jebel Sahaba, c. 12,000-10,000 BC ${ }^{4}$. With respect to Neolithic and early Predynastic periods, human remains with injuries that could have been provoked by violent episodes in a warlike context have been found - skulls with injuries apparently caused by blunt instruments in sites such as Merimde Beni-Salame, Mostagedda, el-Omari and Hierakonpolis, and "parry fractures" - i.e. in the forearms - documented in a series of graves in Mostagedda, Maadi and Adaïma.

There are also numerous weapons, such as maces, arrows, spears and axes, whose military use, thou not the unique possible one, is attested in early representations of human figures wielding such objects in military scenes ${ }^{5}$.

Another set of testimonies of war found in the Nile Valley consists of fortifications and defensive settlement patterns. On the one hand, as stated by Gregory Gilbert, Neolithic compounds "located in naturally defensible sites, often on slightly higher ground at the end of spurs along the desert edge", suggest a warlike environment in which "settlement compounds may have acted as refuges using the natural advantages of the terrain" ". On the other hand, fortifications have been testimonied from a clay model found at Abadiya (Naqada I), representing two individuals standing behind a crenellated, probably defensive wall, and from the remains of a mudbrick wall two meters thick (Naqada II), found in Naqada South Town?

But more importantly for the issue we are dealing with, there is evidence of warlike activities in iconographic representations. This kind of evidence is of particular relevance, because it provides information on both the existence of war and how it may have been perceived by the society.

In the Nile Valley, the earliest known scenes related to war, dated to Naqada Ic period, are few but significant, particularly if they are considered in the light of later evidence. A decorated vessel found in the tomb U-239 from the cemetery $U$ at Abydos represents a human figure wearing a headdress - probably made of feathers - and an animal tail, and holding a mace with which it is very likely about to smite a group of smaller figures that some authors have identified as prisoners (Fig. 1). Certainly, this motif brings to mind the Pharaonic scenes of the king smiting his enemies. Brussels E3002 vessel displays a similar motif (Fig. 2).

It represents two human figures - or perhaps one figure in two moments of a sequencewith arms raised, each of them wearing a headdress and an animal tail, and one of which is holding by their necks, with a rope, a number of small-size figures - probably captives. The motif of the London UC15339 vessel represents two human figures of different sizes, the largest one with arms raised - similar to the figures of the Brussels E3002 vessel and of one of the figures of the U-239 vessel-, apparently attacking with a spear or holding with a rope the smaller one (Fig. 3).

4 Wendorf, 1968; Wendorf \& Schild, 1986. In relation to the individual with stone projectil points found at Wadi Kubbaniya, Béatrix Midant-Reynes $(1992,70)$ has stated that it is reminiscent of the violence that seems to have provoked the death of the individuals found in the Qadan cemetery 117 at Jebel Sahaba, this last one containing 59 skeletons of which $40 \%$ had stone projectile points, whether embedded in the bones or intimately associated with them.

5 Gilbert, 2004, 33-72. See Campagno, 2004, 689, n. 1.

6 Gilbert, 2004, 100-101.

7 According to Bruce Williams (1994, 280, and 278), it is most "likely that fortified settlements appeared almost as soon as Neolithic settlement in the valley", thus suggesting that "the security problem was persistent or recurrent" in the Nile Valley. See Campagno, 2004, 689-690; Gilbert, 2004, 97, 103; Heagren, 2010, 100. On the Abadiya clay model, see Hoffman, 1979, 148; Midant-Reynes, 1992, 192. On the Naqada South Town wall, see Gilbert, 2004, 102-103. 


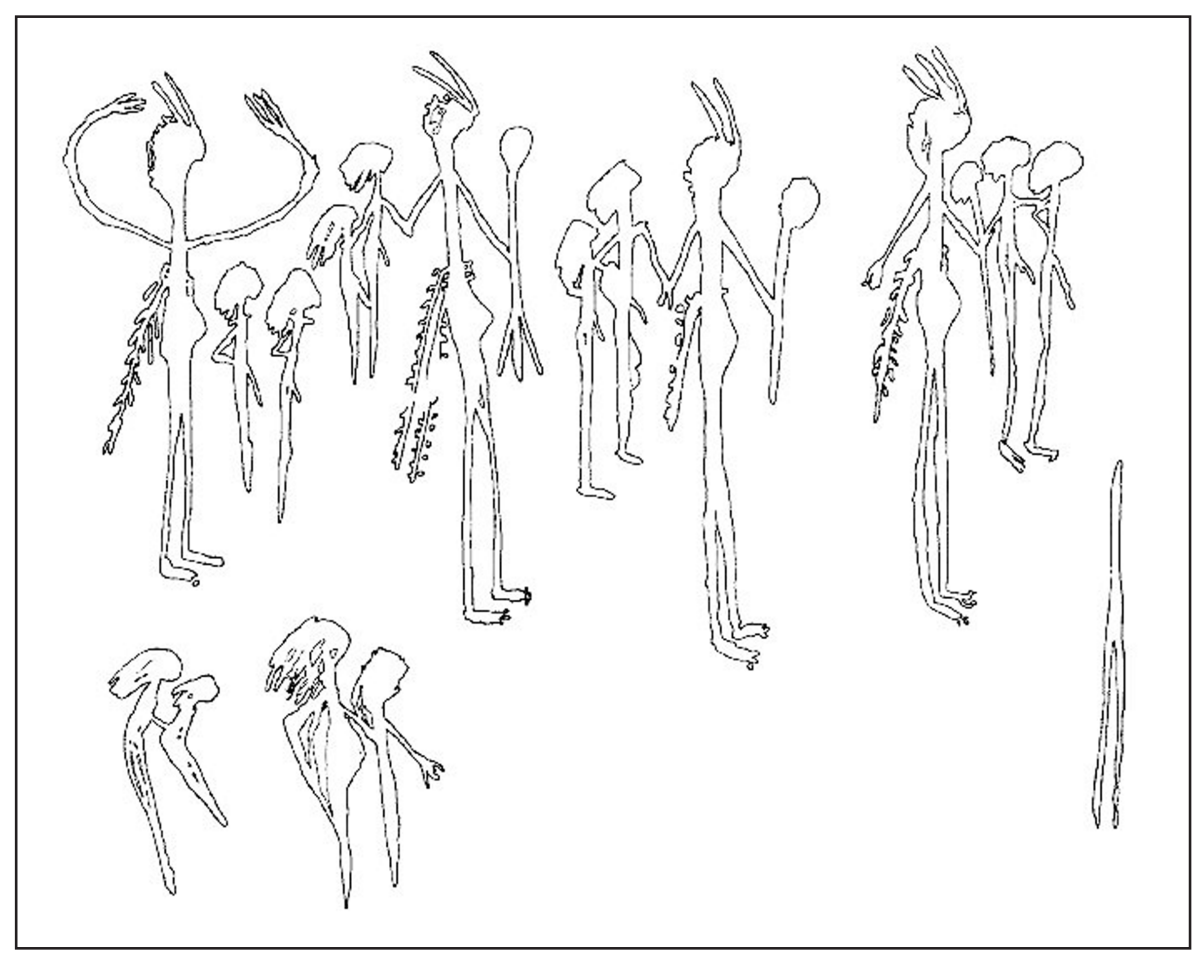

Figura 1. Motif in vessel from tomb U-239 in Abydos (Dreyer et al., 1998, 114). Vessel height: $29.8 \mathrm{~cm}$.

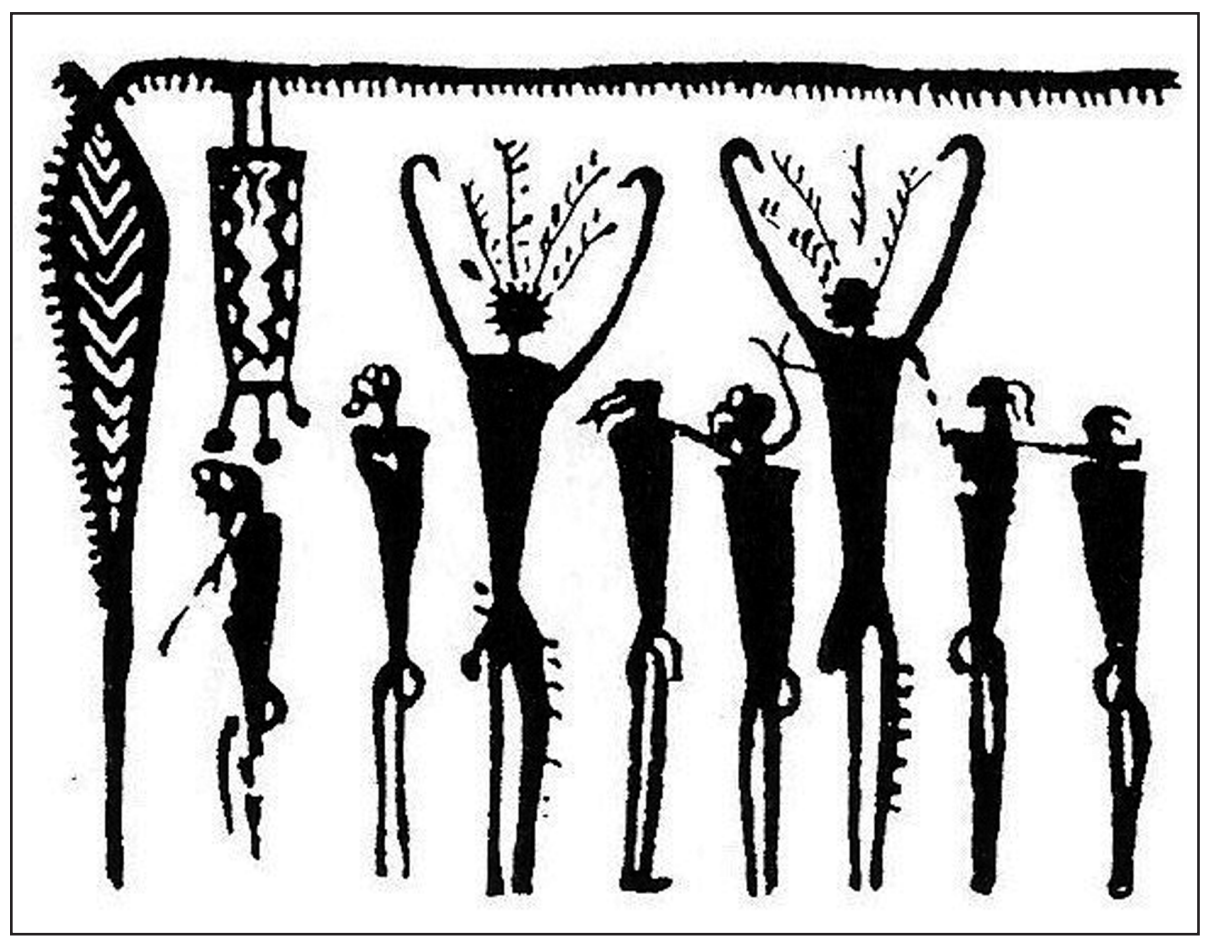

Figura 2. Motif in Brussels E3002 vessel (Vandier, 1952, 187). Vessel height: $28.6 \mathrm{~cm}$. 


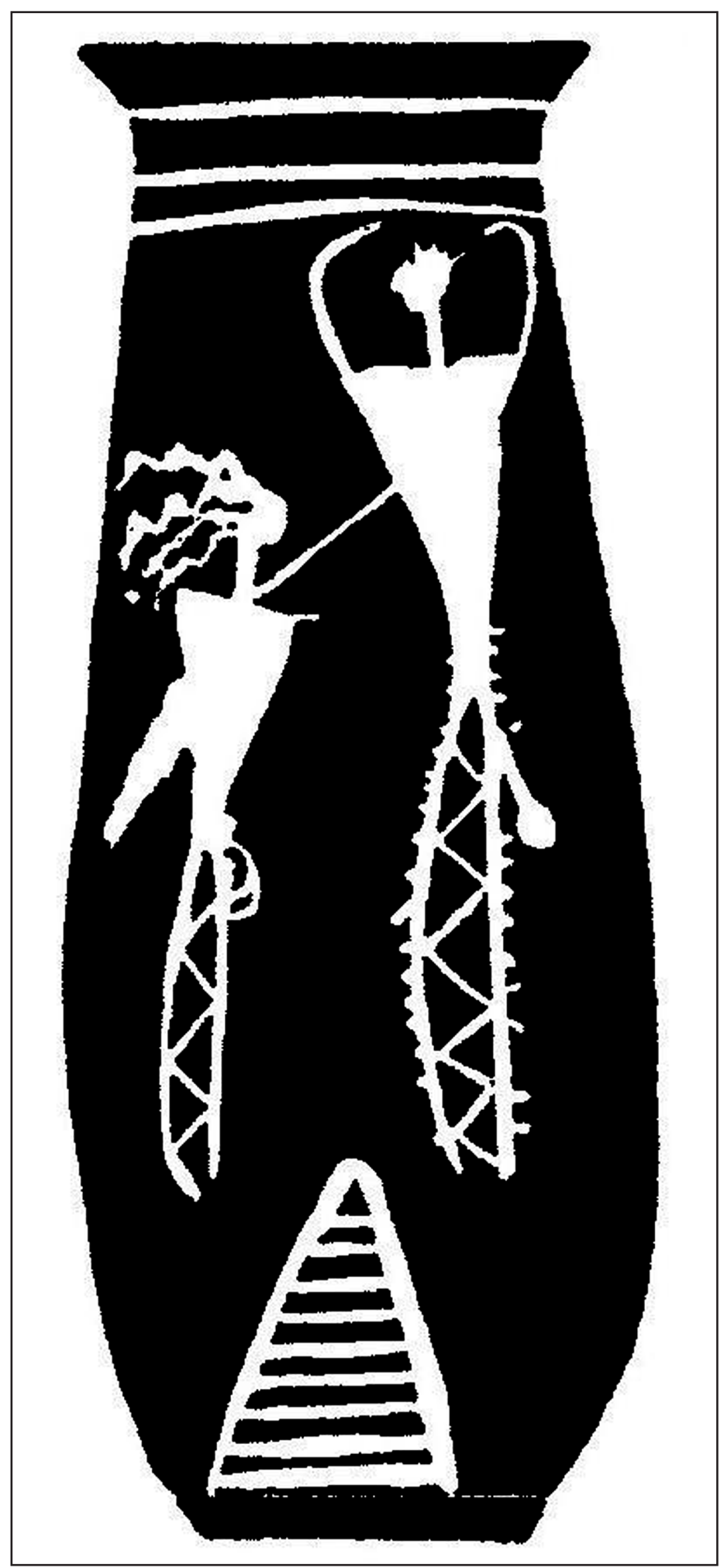

Figura 3. Motif in London UC15339 vessel (Petrie, 1920, pl. XVIII.74). Vessel height: $31.5 \mathrm{~cm}$. 
Finally, we have a scene in a vessel found in the tomb U-415 at Abydos, in which a large figure with a headdress, an animal tail, a penis sheath and what could be interpreted as a mace, is holding with a rope a number of figures that have been identified as prisoners (Fig. 4) ${ }^{8}$.
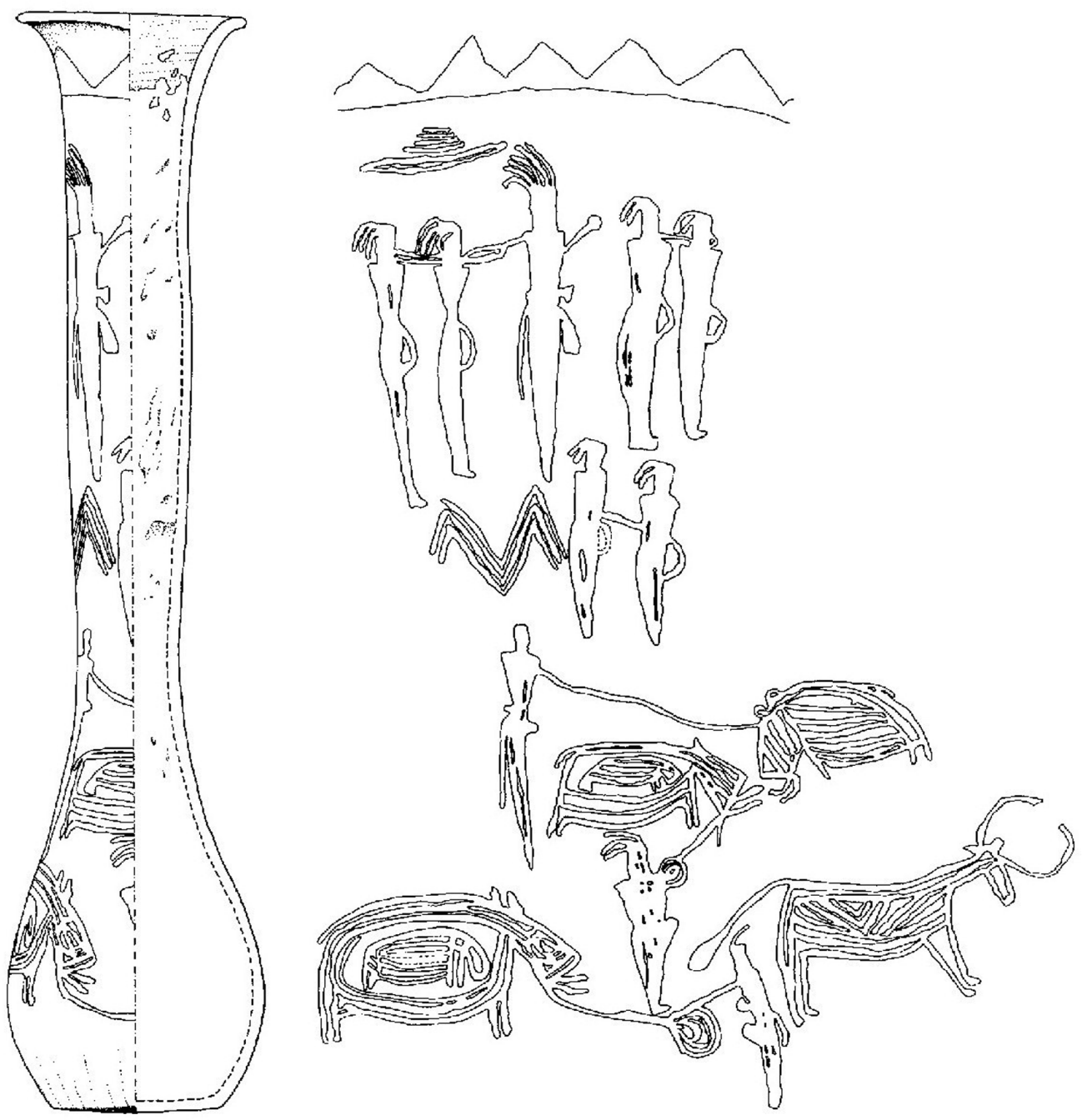

Figura 4. Motif in vessel from tomb U-415 in Abydos (Dreyer et al., 2003, 80). Vessel height: $50.6 \mathrm{~cm}$.

It is worth noting that these scenes seem to evoke not only what appears to be a context of warlike conflicts, but also the existence of figures who seem to wield some sort of prestige linked - in one way or another - to the realm of war ${ }^{9}$. This last inference is based not only on

8 On the decorated vessels found in tombs U-239 and U-415, see Dreyer et al., 1998, 84, 111-115; 2003, 80. On the Brussels E3002 and London UC15339 vessels, see Petrie, 1920, pl. XVIII.74; Vandier, 1952, 287. Also a clay statuette of a figure with arms crossed on his back, found in Naqada, has been interpreted as an early representation of a prisoner (Schäfer, 1896, 159-160, and fig. 3; Vandier, 1952, 433, and fig. 291).

9 See Köhler, 2002, 504; Gayubas, 2006, 63-65. 
the relative size of the figures, but also on a number of features that we would like to outline in the following paragraphs.

We have pointed out that in some of these motifs, the leading figure presents his arms raised - U-239, E3002 and UC15339-, and they, according to Hendrickx, Huyge and Wendrich, "are to be considered a symbol of power, referencing bull horns"10. Bull horns are part of the Pharaonic symbolism, but most likely also of the non-State leadership of Predynastic societies, representing the military attribute of the leader — chief or king.

The action represented, in which the larger figure with a headdress - leader or chiefsmites with a mace or holds with a rope the smaller figures, also provides evidence which may suggest a link between leadership and the military. Whether representing a fighting, an execution, a postwar ritual or a sacrifice, the idea of the subjugation of the enemy is clear beyond doubt $^{11}$.

The use of the mace also has considerable significance. As some scholars have argued the mace acquired during Predynastic times a significant meaning as a symbol of power, most likely linked to the practical utility of the mace as a weapon of war and execution and perhaps as an expression of the prestige obtained by war leaders during military activity. Its use as a manifestation of the martial aspect of the king in Pharaonic periods may well be traced back to its use with similar meanings by the leaders of the Predynastic period ${ }^{12}$.

For its part, the animal tail — probably of a bull - wore by the figures portrayed, was a characteristic attribute of the royal authority in Pharaonic times. Its association with the realm of hunting and with the attributes of strength, skill and coordination abilities - essential characteristics of both hunting and war leaders - links it to warlike activities ${ }^{13}$. In fact, in the motif of the U-415 decorated vessel, the smiting scene is combined with a hunting - of the hippopotamus - scene, thus "confirming the symbolic meaning of the latter" 14 . This combination would be present in later periods, such as in a seal impression of the king Den of the First Dynasty, in which the king is represented hunting a hippopotamus next to a representation of beheaded captives ${ }^{15}$.

There is more explicit evidence related to war and leadership in later contexts. For example, the Gebelein painted linen, usually dated to Naqada IIa period, contains the motif of a bounded prisoner in the cabin of a boat, with what appears to be a mace suspended above his head. In a contiguous boat, a figure sitting on a throne is holding a sort of flail and wearing some kind of crown. The wall painting in Tomb 100 at Hierakonpolis, dated to Naqada IIc, represents an individual — warrior, chief, king? — smiting smaller figures — probably defeated enemies - similar to the motifs of vessels from the tombs U-239 and U-415 at Abydos, and to the Pharaonic smiting scene formalized in the Narmer Palette ${ }^{16}$.

Other significant scenes in this painting are two individuals armed with staffs, one also with a shield, engaging in hand to hand combat, and the motif of a man dominating two wild animals, which also appears in the Gebel el-Arak knife handle - in which there appears also a formidable battle between individuals armed with maces, staffs and knives - and in various Saharan and Nilotic rock carvings. This latter motif seems to evoke - in a way that was not

10 Hendrickx, Huyge \& Wendrich, 2010, 27.

11 Köhler, 2002, 503-504; Gilbert, 2004, 88-92.

12 Hoffman, 1982, 145; Gilbert, 2004, 35-41; Gayubas, 2006, 63.

13 Cervelló Autuori, 1996, 73.

14 Hendrickx \& Förster, 2010, 830, and fig. 37.2. See Köhler, 2002, 508-509.

15 Müller, 2008; Hendrickx \& Förster, 2010, 830, and fig. 37.4; Hendrickx, 2014, 269. See Säve-Söderbergh, 1953.

16 On the Gebelein painted linen (Egyptian Museum of Turin, S. 17138), see Williams \& Logan, 1987, 255-256, 279. On the wall painting in Tomb 100 (fragments preserved in the Egyptian Museum in Cairo), see Quibell \& Green, 1902, pls. LXXV-LXXVIII; Gilbert, 2004, 86-89. 
formalized in Pharaonic times - the Egyptian idea of the "containment of unrule", the foundations of which would be both ideological and political, focusing on the domination by the leader of all the forces of chaos —including the enemies of the community ${ }^{17}$.

3.

In his aforementioned article, Carneiro stated that even in absence of a context of environmental circumscription, war among non-State societies was endemic. Taking into account ethnographic and archaeological testimonies, he claimed that "we can state with assurance that even before the rise of chiefdoms, warfare was already present and active in the relation among villages" ${ }^{18}$. Anthropologist Pierre Clastres postulated in the 1970s the existence of a "permanent state of war" among non-State societies, meaning that it "is not the limited reality of armed conflict or combat that is essential, but the permanence of its possibility"; that is, a state of continuous hostility that "maintains all communities in their respective difference" 19 . The evidence considered above seems compatible with this kind of anthropological statement.

If we relate archaeological testimonies of war with those of the centrality of kinship as the main axis for the articulation of society in pre-State societies of the Nile Valley (see above), we can propose that, since kinship regulates the community establishing membership — kin — and exclusion - non-kin - criteria, war in these contexts can be interpreted as the extreme expression of the antagonism between Us and Them that is implicit in kinship ${ }^{20}$. As Campagno puts it, kinship "constitutes the dominant practice within each community, but it does not extend its pattern beyond its limits, and, in fact, the typical relationship of a community with the exterior is - in kinship terms - a non-relationship, based on the distrust of the stranger, the other" 21 .

But warfare can also create the conditions for the emergence of leaders because people who is "succesful in leading and/or defending against aggression would have gained access to broader roles" 22 . As seen above, testimonies relating warlike activities to leadership have been found at least by the early Predynastic period in the Nile Valley. At this period there is also evidence - mainly funerary - that is indicative of the existence of what can be interpreted as chiefdom societies ${ }^{23}$. This leads us once again to Carneiro's statements.

Back in the 1980s, almost two decades after the original formulation of Carneiro's circumscription theory, Bard and Carneiro had proposed a link between war and the emergence of chiefdom societies in the Nile Valley, understood as an evolutionary process of aggregation and conquest of villages determined by a context of environmental circumscription and popu-

17 Kemp, 2006, 92-99. On the Narmer Palette, see Köhler, 2002. On the Gebel el-Arak knife handle, see Emery, 1961, 39; Gilbert, 2004, 93-94. On the scenes of a man dominating wild animals in Saharan and Nilotic rock carvings, see Cervelló Autuori, 1996, 71-72; Campagno, 2010.

18 Carneiro, 2012, 16.

19 Clastres, 1994 [1980], 163.

20 Gayubas, 2014, 158.

21 Campagno, 2004, 690, n. 2. See Campagno, 2000a; 2009. As stated by Glenn Bowman (2001, 42), antagonism "may precisely provide the spur that drives an entity to mark out the boundaries of its identity and to 'defend' them with violence".

22 Neves, 2009, 163.

23 Here we follow Campagno's characterization of a chiefdom as a society with some kind of social differentiation (an elite with privileged access to the consumption of goods and/or certain leadership positions), some institutionalized form of leadership (the figure of a "chief") based on prestige and not on the monopoly of the legitimate use of physical force, and the predominance of the logic of kinship as the main axis for the articulation of society (Campagno, 2000b). 
lation pressure ${ }^{24}$. Although the circumscription condition of the Nile Valley couldn't be verified, and thus the circumscription hypothesis was put into question by several authors - and was abandoned by Bard in the early 1990s-, Carneiro still considers it as explicative, if not of the existence of warfare itself, at least of its relation to the emergence of chiefdoms in the Nile Valley ${ }^{25}$.

An alternative proposition within the circumscription hypothesis is that of Antonio Pérez Largacha, according to which the Upper Egyptian expansion that gave rise to the Egyptian State was determined by a "geographic/commercial circumscription", in the sense that Upper Egyptian elites that demanded exotic goods only available via Lower Egypt were in a geographically circumscribed position that forced them to expand northwards in order to control access to those goods ${ }^{26}$. However, the author doesn't deal — since it is not his aim - with the emergence of institutionalized leadership or chiefdoms prior to the State.

Egyptologist Branislav Anđelković recently stressed the importance of conflict in relation to the emergence of sociopolitical hierarchies in the Nile Valley, recovering Carneiro's assumptions about circumscription, but pointing out that conflict would have been over power, not over scarce resources - since, as stated before, the "natural resources and energetic potential were more than abundant in the Nile valley" in these periods ${ }^{27}$. However, this hypothetical "will to power" that would have led to a fight over territory in a - yet unproven - circumscribed context seems more related to State expansive dynamics —although the idea of a "will to power" remains problematic - than to non-State societies, whose tendency is not to expand themselves but - according to ethnographic analyses - to remain as autonomous entities ${ }^{28}$.

However, what deserves attention about Carneiro's reassessment is his change of opinion regarding the way in which warfare produced its "centripetal" effects -i.e., the emergence of chiefdoms-, moving his emphasis from the "successive military conquest of one village after another" to "the actions of the ad hoc war leader of a village who, acting as the head of an alliance, repeatedly and successfully led a group of villages in military actions against their enemies" 29 . Although a war leader's authority would last "only during war time", as Carneiro - and other anthropologists before him - recognizes, specific circumstances can create the conditions for a different scenario. At this point, Carneiro seems to follow Elsa Redmond who, based on a comparative study of a number of non-State societies in South America, argued that "in the face of escalating warfare, there will be a continuing need for mobilizing allied war parties. Those distinguished war leaders who have built up a large network of supravillage alliances and obligations, who can mobilize large fighting forces on short notice, will be poised for positions of permanent leadership [...]. Their authority will persist in peacetime as well" ${ }^{30}$. Thus, a context of intensification and unpredictability of warlike episodes would be of

24 Bard \& Carneiro, 1989.

25 Carneiro, 2012, 22, 16. See Bard, 1992; Campagno, 2004, 693; Hendrickx, 2014, 263. On the difficulties of postulating a scenario of population pressure for these periods in the Nile Valley, see Butzer, 1976, 84-85; Hoffman, 1979 , 343. See also Cardoso, 1990, 40; Kemp, 2006, 73.

26 Pérez Largacha, 1996.

27 Anđelković, 2004, 542. See also Gilbert $(2004,29)$, according to whom in the Nile Valley "during the Late Neolithic period a local war leader may have become a 'big man",, influencing in some way the establishment of a chiefdom leadership in Predynastic Nile Valley societies.

28 Clastres, 1994 [1980], 115.

29 Carneiro, 2012, 17.

30 Redmond, 1994, 130. According to Jürg Helbling (2006, 123), "a political leader delivers collective goods by organising and co-ordinating war campaigns and alliances, as well as by contributing more than other group members to alliance feasts and compensation payments. For his superior contribution to the military success of the group, he is awarded high status and a good reputation, as long as he delivers". The military feature, therefore, remains important even in circumstances where social differentiation involves the performance of different functions by the chiefs - beyond a 
importance to understand how "the temporary grouping of allied villages under the authority of [...] a war leader would be made permanent and institutionalized"31.

In the Nile Valley, such a scenario can be proposed in relation to the population movements that have occurred in the VI-V millennia BC, caused by the intensification of aridization that was transforming the savannas surrounding the Nile Valley into what are now the eastern and western deserts of Egypt. Hunter-gatherer - and perhaps herder - populations from the surrounding regions of the Nile Valley would come into contact with each other and with the presumably hunter-gatherer and fisher populations of the valley ${ }^{32}$. Human remains attesting injuries probably owed to warfare, defensive settlement patterns in some regions of the valley, and the first war maces, have been found for this period, thus suggesting the conflictive character of these contacts.

Contrary to what the circumscription theory would suggest, the context of wide availability of land and resources in the Nile Valley prevents us to consider these conflicts in the sense of a struggle for resources ${ }^{33}$. Fekri Hassan noted that the way these kinds of population movements took place, as well as any other decision related to them, would have relied not only on ecological conditions, but also on cultural dispositions ${ }^{34}$. In effect, territory in this kind of scenario should be interpreted by paying attention to the "spatial unity of the habitat" ("the people who belong to the same community live together in the same place"), a term by which Pierre Clastres emphasized the social aspect of territory, i.e. that the "locality of the local group is [...] its territory, as a natural reserve of material resources, certainly, but especially as an exclusive space for the exercise of community rights" 35 . In this sense, it is the political unity of the community and its own perception of its rights over the habitat what is crucial, and what defines the exclusivity of territory in terms of the exclusion of the Others from rights over that space and its resources - thus expressing the antagonism between communities that is implicit in kinship.

During the early Predynastic period, in a context of increasing sedentarization and the establishment of more permanent settlements in the Nile Valley, conformation of inter-communal relations presumably characterized by an alternation of warfare and exchange activities would have allowed the establishment of more stable alliances whose coordination would be a privileged aspect of leadership.

strictly military one. Carneiro himself $(2012,18)$ remarks that if "the person who repeatedly and successfully led allied villages in war was not actually a specially designated war chief, but was the regular village chief, elevated in time of war to the position of military commander of an alliance of villages, with his powers augmented accordingly, the scenario outlined above would still hold".

31 Redmond, 1994, 130. In a similar sense, Claus Bossen $(2006,98)$ argues that a process of emergence of sociopolitical hierarchies related to the military realm may take place "in circumstances where a society is under constant threat of being annihilated".

32 Hassan, 1988, 144; Bard, 1994, 24-25. Regarding connections between eastern Sahara and the Nile Valley, see Cervelló Autuori, 1996, 80-92; Le Quellec, Flers \& Flers, 2005; Wengrow, 2006, 18-21; Bárta, 2014.

33 Pre-existence of warlike activities, as well as the fact that population movements may have occurred during a long span of time, prevent from a pure deterministic approach. However, as stated by anthropologist Paul Sillitoe (1977, 80), ecological conditions should be taken into consideration, if not as an explicative variable by itself, "as one of the several important factors which must be considered in a comprehensive analysis of primitive war".

34 Hassan, 2002a, 16. See also Hassan, 2002b, 330. This is illustrated by an interesting ethnographic source, significantly mentioned by Carneiro: among the Mae Enga of the highlands of New Guinea, warfare was sometimes conducted in order to obtain what was interpreted as "increasingly scarce" arable land. However, as anthropologist Mervyn Meggitt (1977, 182-183) recognized, land and resources weren't scarce among the Mae Enga. The Mae Enga fought for land as well as for other reasons, but in a context lacking verifiable material scarcity. See Ember \& Ember, 1992.

35 Clastres, 1994 [1980], 153-154. Anđelković (2004, 542-543) makes an interesting distinction between fight over "land" and fight over "territory" in the Nile Valley, although emphasizing — as already mentioned — the idea of a "will to power". 
Summarizing, population movements in the Nile Valley may have created a context of intensification and unpredictability of warlike conflicts related to a communal perception of the "spatial unity of the habitat", that could have enhanced the military aspect of leadership, including - specially in the context of sedentarization - the skills of the leader to forge alliances, mobilize followers, and manage resources. The forms of representing leaders in the Naqada I-II periods, in scenes of warlike violence and hunting activities - a practice with strong military symbolism-, seem to support this interpretation ${ }^{36}$.

To conclude, although circumscription theory remains flawed in deal with the emergence of chiefdom societies in the Nile Valley, the available evidence of warlike activities in the periods considered allow us to suggest that warfare - i.e. Carneiro's privileged "mechanism" - is of central importance in understanding the emergence of institutionalized leadership in early Predynastic Nile Valley.

\section{BIBLIOGRAPHY}

Anđelković, B. (2004): "The Upper Egyptian Commonwealth: A Crucial Phase of the State Formation Process", S. Hendrickx, R. F. Friedman, K. M. Ciałowicz \& M. Chłodnicki (eds.), Egypt at its origins. Studies in Memory of Barbara Adams. Proceedings of the International Conference "Origin of the State. Predynastic and Early Dynastic Egypt". Leuven: 535-546.

Bard, K. A. (1992): "Toward an Interpretation of the Role of Ideology in the Evolution of Complex Society in Egypt". Journal of Anthropological Archaeology 11: 1-24.

Bard, K. A. (1994): From Farmers to Pharaohs. Mortuary Evidence for the Rise of Complex Society in Egypt. Sheffield.

Bard, K. A. \& Carneiro, R. L. (1989): "Patterns of Predynastic Settlement Location, Social Evolution, and the Circumscription Theory". Cahiers de Recherches de l'Institut de Papirologie et d'Egyptologie de Lille 11: 15-23.

Bárta, M. (2014): "Prehistoric mind in context. An essay on possible roots of Ancient Egyptian civilization", K. Kristiansen, L. Šmejda \& J. Turek (eds.). Paradigm Found: Archaeological Theory Present, Past and Future. Essays in Honour of Evžen Neustupný. Oxford: 188-201.

Bossen, C. (2006): "War as Practice, Power, and Processor: A Framework for the Analysis of War and Social Structural Change", T. Otto, H. Thrane \& H. Vandkilde (eds.). Warfare and Society. Archaeological and Social Anthropological Perspectives. Aarhus: 89-102.

Bowman, G. (2001): "The violence in identity”, B. E. Schmidt \& I. W. Schröder (eds.), Anthropology of Violence and Conflict. London: 25-46.

Butzer, K. W. (1976): Early Hydraulic Civilization in Egypt: A Study in Cultural Ecology. ChicagoLondon.

Campagno, M. (2000a): "Kinship and the Emergence of the State in Egypt". Bulletin of the Australian Centre for Egyptology 11: 35-47.

Campagno, M. (2000b): "Hacia un uso no-evolucionista del concepto de 'sociedades de jefatura". Boletín de Antropología Americana 36: 137-147.

Campagno, M. (2004): "In the beginning was the War. Conflict and the emergence of the Egyptian State", S. Hendrickx, R. F. Friedman, K. M. Ciałowicz \& M. Chłodnicki (eds.), Egypt at its origins. Studies in Memory of Barbara Adams. Proceedings of the International Conference "Origin of the State. Predynastic and Early Dynastic Egypt”. Leuven: 689-703.

36 In relation to the war leader, Carneiro $(2012,18)$ makes an interesting observation by asserting that "a coterie of redoubtable warriors" would become "personally loyal" to the leader, thus contributing to his establishment as "permanent chief". This can perhaps be related to the emergence of relations of personal subordination in some way or another linked to future kingship in Egypt. For a compatible statement but in relation to sacred leadership, see Campagno, 2014, 14-19. The sacred condition of leadership is not necessarily opposed to the military, as it is revealed by the fact that physical force and cosmic power are closely linked throughout ancient Egyptian history. 
Campagno, M. (2009): “Kinship and Family Relations”, E. Frood \& W. Wendrich” (eds.), UCLA Encyclopedia of Egyptology. Los Angeles: <http://repositories.cdlib.org/nelc/uee/1043>.

Campagno, M. (2010): "Encore une réflexion sur le motif prédynastique du Maître des Animaux". $\mathrm{Ca}$ hiers Caribéens d'Egyptologie 13-14: 115-132.

Campagno, M. (2014): "Patronage and Other Logics of Social Organization in Ancient Egypt during the IIIrd Millennium BCE”. Journal of Egyptian History 7: 1-33.

Campagno, M. \& Gayubas, A. 2015: "La guerra en los comienzos del antiguo Egipto: reflexiones a partir de la obra de Pierre Clastres". Cuadernos de Marte. Revista latinoamericana de sociología de la guerra 8: 11-46.

Cardoso, C. F. S. (1990): Antigüidade oriental: política e religião. São Paulo.

Carneiro, R. L. (1970): “A Theory of the Origin of the State”. Science 169: 733-738.

Carneiro, R. L. (2012): "The Circumscription Theory: A Clarification, Amplification, and Reformulation". Social Evolution \& History 11 (2): 5-30.

Cervelló Autuori, J. (1996): Egipto y África. Origen de la civilización y la monarquía faraónicas en su contexto africano. Sabadell.

Clastres, P. (1994 [1980]): Archaeology of Violence. New York.

Dreyer, G.; Hartung, U.; Hikade, T.; Köhler, E. C.; Müller, V. \& Pumpenmeier, F. (1998): "Umm elQaab. Nachuntersuchungen im frühzeitlichen Königsfriedhof. 9./10. Vorbericht”. Mittelungen des Deutschen Archäologischen Instituts abteilung Kairo 54: 77-167.

Dreyer, G.; Hartmann, R.; Hartung, U.; Hikade, T.; Köpp, H.; Lacher, C.; Müller, V.; Nerlich, A. \& Zink, A. (2003): "Umm el-Qaab. Nachuntersuchungen im frühzeitlichen Königsfriedhof". 13./14./15. Vorbericht. Mittelungen des Deutschen Archäologischen Instituts abteilung Kairo 59: 67-138.

Ember, C. R. \& Ember, M. (1992): "Resource Unpredictability, Mistrust and War. A Cross-Cultural study". Journal of Conflict Resolution 36 (2): 242-262.

Emery, W. B. (1961): Archaic Egypt. Harmondsworth.

Gayubas, A. (2006): "Guerra, parentesco y cambio social en las sociedades sin Estado del valle del Nilo prehistórico", M. Campagno (ed.), Estudios sobre parentesco y Estado en el antiguo Egipto. Buenos Aires: 51-73.

Gayubas, A. (2014): "Pierre Clastres y la guerra en el valle del Nilo preestatal”, M. Campagno (ed.), Pierre Clastres y las sociedades antiguas. Buenos Aires: 143-162.

Gilbert, G. P. (2004): Weapons, Warriors and Warfare in Early Egypt. Oxford.

Hassan, F. A. (1988): "The Predynastic of Egypt". Journal of World Prehistory 2: 135-185.

Hassan, F. A. (2002a): "Paleoclimate, Food and Culture Change in Africa: An Overview", F. A. Hassan (ed.), Droughts, Food and Culture. Ecological Change and Food Security in Africa's Later Prehistory. New York: 11-26.

Hassan, F. A. (2002b): "Conclusion: Ecological Changes and Food Security in the Later Prehistory of North Africa: Looking Forward", F. A. Hassan (ed.), Droughts, Food and Culture. Ecological Change and Food Security in Africa's Later Prehistory. New York: 321-333.

Heagren, B. H. (2010): The Art of War in Pharaonic Egypt. An Analysis of the Tactical, Logistic, and Operational Capabilities of the Egyptian Army (Dynasties XVII-XX), Doctoral dissertation, Auckland.

Helbling, J. (2006): "War and Peace in Societies without Central Power: Theories and Perspectives", T. Otto, H. Thrane \& H. Vandkilde (eds.), Warfare and Society. Archaeological and Social Anthropological Perspectives. Aarhus: 113-139.

Hendrickx, S. (2014): “The emergence of the Egyptian state", C. Renfrew \& P. Bahn (eds.), The Cambridge World Prehistory, vol. 1, Cambridge: 259-278.

Hendrickx, S. \& Förster, F. (2010): "Early Dynastic Art and Iconography", A. B. Lloyd (ed.), A Companion to Ancient Egypt, vol. 2. Oxford: 826-852.

Hendrickx, S. \& Veermersch, P. (2000): "Prehistory. From the Palaeolithic to the Badarian Culture (c. 700,000-4000 BC)", I. Shaw (ed.), The Oxford History of Ancient Egypt. New York: 17-43.

Hendrickx, S., Huyge, D. \& Wendrich, W. (2010): "Worship without Writing”, W. Wendrich (ed.), Egyptian Archaeology. Oxford: 15-35.

Hoffman, M. A. (1979): Egypt Before the Pharaohs. New York.

Hoffman, M. A. (1982): The Predynastic of Hierakonpolis: An interim report. Giza-Macomb.

Kemp, B. J. (2006): Ancient Egypt: Anatomy of a Civilisation, 2nd ed. London-New York. 
Köhler, E. C. (2002): "History or Ideology? New Reflections on the Narmer Palette and the Nature of Foreign Relations in Pre- and Early Dynastic Egypt", E. C. M. van den Brink \& T. E. Levy (eds.), Egypt and the Levant. Interrelations from the 4th through the early 3rd Millennium BCE. London: 499-513.

Le Quellec, J.-L.; Flers, P. de \& Flers, P. de (2005): Du Sahara au Nil: peintures et gravures d'avant les pharaons. Paris.

Meggitt, M. (1977): Blood is their Argument. Warfare among the Mae Enga Tribesmen of the New Guinea Highlands. Palo Alto.

Midant-Reynes, B. (1992): Préhistoire de l'Egypte. Des premiers hommes aux premiers Pharaons. Paris.

Müller, V. (2008): "Nilpferdjagd und geköpfte Feinde - zu zwei Ikonen des Feindvernichtungsrituals", E.-M. Engel; V. Müller \& U. Hartung (eds.), Zeichen aus dem Sand. Streiflichter aus Ägyptens Geschichte zu Ehren von Günter Dreyer. Wiesbaden: 477-493.

Neves, E. G. (2009): "Warfare in Precolonial Central Amazonia: When Carneiro Meets Clastres", A. Nielsen \& W. Walker (eds.), Warfare in Cultural Context. Practice, Agency, and the Archaeology of Violence. Tucson: 140-164.

Pérez Largacha, A. (1996): "The Rise of Egyptian State and Carneiro Circumscription Theory". Cahiers de Recherches de l'Institut de Papyrologie et d'Égyptologie de Lille 18: 107-118.

Petrie, W. M. F. (1920): Prehistoric Egypt. London.

Quibell, J. E. \& Green, F. W. (1902): Hierakonpolis. Part II. London.

Redmond, E. M. (1994): Tribal and Chiefly Warfare in South America. Ann Arbor.

Säve-Soderbergh, T. (1953): On Egyptian Representations of Hippopotamus Hunting as a Religious Motive. Uppsala.

Schäfer, H. (1896): “Neue Altertümer der 'new race' aus Negadeh”. Zeitschrift für Ägyptische Sprache und Altertumskunde 34: 158-161.

Sillitoe, P. (1977): "Land Shortage and War in New Guinea". Ethnology 16 (1): 71-81.

Vandier, J. (1952): Manuel d'Archeologie Égyptienne. 1. Les époques de formation. 1. La préhisoire. Paris.

Wendorf, F. (1968): "Site 117: A Nubian Final Palaeolithic Graveyard near Jebel Sahaba, Sudan”, F. Wendorf (ed.), The Prehistory of Nubia, vol. 2. Dallas: 954-995.

Wendorf, F. \& Schild, R. (1986): The Wadi Kubbaniya Skeleton: A Late Paleolithic Burial from Southern Egypt. Dallas.

Wengrow, D. (2006): The Archaeology of Early Egypt. Social Transformations in North-East Africa, c. 10,000 to 2,650 BC. Cambridge.

Williams, B. B. (1994): "Security and the Problem of the City in the Naqada Period", D. P. Silverman (ed.), For His Ka: Essays in Memory of Klaus Baer. Chicago: 271-283.

Williams, B. B. \& Logan, T. J. (1987): "The Metropolitan Museum knife handle and aspects of Pharaonic imagery before Narmer". Journal of Near Eastern Studies 46: 245-285.

Recibido: $28 / 11 / 2014$

Aceptado: 24/05/2015 